\title{
Availability and Use of Mobile Phones for Information Dissemination by Public Extension Agents in Delta State, Nigeria
}

\author{
Egbule, C. L. ${ }^{1}$, Agwu, A. E. ${ }^{1}$ and Uzokwe, U. N. ${ }^{2}$ \\ ${ }^{1}$ Department of Agricultural Extension \\ University of Nigeria, Nsukka. E-mails: chukwudumebi.egbule@unn.edu.ng, dumexbi@yahoo.com \\ Phones: +234-8038844428 \\ ${ }^{1}$ Department of Agricultural Extension \\ University of Nigeria, Nsukka. E-mails: agwuekwe@hotmail.com, ekwe.agwu@unn.edu.ng \\ Phones: +234-8034024251 \\ ${ }^{2}$ Department of Agricultural Economics and Extension \\ Delta State University, Asaba Campus \\ Asaba, Delta State, Nigeria. E-mails: ucheadauzokwe@yahoo.com \\ Phones: $+234-8032054594$
}

\begin{abstract}
The study assessed the availability and dissemination of information to farmers using mobile phones by public extension agents in Delta state, Nigeria. Data were collected from 64 randomly selected public extension agents from the three agricultural zones in the state. Majority (98.4\%) of the extension agents were not provided with institutional mobile phones to aid information dissemination to clientele. However, about $97 \%$ of the respondents affirmed that they possess personal mobile phones, which they (92\%) use to disseminate information to farmers. Interactions with farmers were mainly through phone calls (84.4\%) and short message services (SMSs) (71.9\%). Mobile phones were frequently used in disseminating information on availability of new crop varieties $(M=2.1)$, and available markets for sale of crop produce $(M=2.0)$. The study points to the need for the public extension service to collaborate with network providers in dissemination of short programmed messages or calls that are beneficial to the farmers as well as creating a hotline desk that will readily provide answers to the immediate needs of farmers. This will facilitate the achievement of the agricultural transformation agenda (ATA) of the federal ministry of agriculture which aims at reaching the farmers with innovative agricultural information as well as agro inputs.
\end{abstract}

Key words: Availability, Use, Mobile phone, Extension agents and Delta state agricultural development programme

\section{Introduction}

For decades traditional forms of ICTs have been used in advisory service provision. Radio and television programs regularly feature weather and agricultural information in developing countries, and rural telecenters have provided information on education and agricultural issues (Goyal, 2010, in Aker, 2011). With the growth of mobile phone coverage, many of these initiatives have moved away from traditional ICTs to the use of mobile phones, including voice, SMS and internet-based services. The number of connected mobile telephones rose from 266,401 in 2001 to $32,322,202$ units in 2006 as at 2010, and the total number of connected mobile telephones in the country was $84,990,100$. Coinciding with this growth in coverage has been an increase in mobile phone adoption and usage by rural farmers, despite their resource poor conditions.

While radios can be used across all segments of the population, it provides limited range of information. Newspapers though accessible, are primarily concentrated in urban areas, and are expensive (the cost of newspapers in Nigeria average $\mathbf{A 1 5 0}$; which is about \$1), and are irrelevant to illiterate populations. 
Less than 19 percent of individuals in sub-Saharan Africa can boost of reading a newspaper at least once per week, with a much smaller share in rural areas. Landline coverage has been limited, with less than one landline subscriber per 1,000 people in 2008 (ITU, 2009). Access to other search mechanisms, such as fax machines, e-mail, and Internet, is similarly low, primarily due to their dependence upon landline infrastructure.

Also, personal travel to different villages and markets to obtain information not only requires transport costs, but also the opportunity costs of an individual's time. This can be substantial in the context of unpaved roads and vast distances. Aker and Mbiti (2010) provided an overview of the mechanisms through which mobile phone telephony can affect economic development in sub-Saharan Africa, including access to information, coordination among agents, job creation, social networks and improved services. In that vein, potential mechanisms through which mobile phones could potentially improve farmers' access to information about agricultural technologies and adoption more generally, and access to and use of agricultural extension services in particular are important.

Agumagu, Adesope, Matthews-Njoku and Nwaogwugwu (2008) noted that the information boom of this century requires that worthwhile strategies of communication be developed and utilized. To meet up with this trend, agricultural extension services need to intensify efforts required to acquire the necessary information and communication technology facilities that will enhance the dissemination of information. In Nigeria today, the Global System of Mobile (GSM) communication has a large market size that cuts across both the urban and rural areas. At the introduction of GSM into the country, the targeted markets were the urban areas but with the installation of masts connecting areas together; service providers have successfully introduced their networks into the rural areas. The availability of networks in the rural areas, have enhanced the use of mobile phones by rural dwellers who are predominantly farmers.

The device has the potentials in bridging the information divide that exist between the urban and rural places. In many countries across the world, the mobile phone has provided a source of employment, has connected individuals to market and prospective buyers of their commodity. It has also the ability to connect people to health, agriculture, and business information.

Availability of mobile phone for information dissemination has direct bearing on dissemination of agricultural information. For example, the agricultural transformation agenda (ATA) of the federal ministry of agriculture aims at having the databases of all farmers in order to facilitate the process of reaching them with innovative agricultural information as well as agro inputs. These the ATA hopes to achieve through communication using the mobile phones. It is not enough to focus on farmers with regards to possession and use of mobile phones. It is pertinent that information dissemination personnel's are also provided with this device to facilitate communication of beneficial agricultural information to farmers; hence this study. Based on the importance of mobile phone in information dissemination, this study set out to ascertain the availability and use of mobile phones for information dissemination by public extension agents in Delta state ADP. Research questions that aided this study were: are there institutional supports in the provision of the device? how often do extension agents (EAs) use mobile phones for information dissemination to their clientele? do extension agents employ the use of SMSs in information delivery? These and other questions were answered by this study. 


\section{Objectives of the study}

Specifically, the study sought to:

1. ascertain institutional support towards provision of mobile phones for information dissemination by public extension agents;

2. determine the frequency of usage of mobile phones for information dissemination by extension agents; and

3. identify the areas of agricultural extension services/information dissemination supported by mobile phone.

\section{Methodology}

The study was carried out in Delta state using multistage sampling technique, the three agricultural zones in the state were selected in the first stage. The second stage was the selection of all the twenty five blocks in the three agricultural zones of the state. Proportionate simple random sampling technique was used to select cells from each of the blocks (third stage). A total of sixty four cells were selected for the study; since an EA is in charge of a cell, the sixty four EAs in the sixty four cells constituted respondents for this study. Data for the study were generated using well structured questionnaire, which contained relevant questions based on the objectives of the study. Objective one and three were analyzed using percentage; objective two was analyzed using mean statistic.

To ascertain the institutional support towards the use of mobile phones in information dissemination, respondents were required to tick against a response option of "yes" or "no", if their institution provided them with mobile phones for communicating with farmers. Respondents were also required to indicate the ownership of mobile phones, with the aim of ascertaining provision of the device by the institution. In ascertaining the means of information dissemination using the mobile phone, a list of options was provided and the respondents were asked to tick the means through which information is communicated to farmers using the mobile phones.

To determine the frequency of usage of mobile phone in information dissemination, options were provided on a 3 point Likert-type scale; each respondent was required to indicate his/her responses by ticking any of the options namely: "very frequent", "frequent", and "not frequent". Values assigned to these options were 3, 2 and 1 respectively. These values were added to obtain 6 , which was divided by 3 to obtain 2 , this was regarded as the mean. Variables with mean score less than 2 revealed low frequency of usage while those with mean score equal or above 2 were taken as having high frequency of usage.

The respondents were also required to indicate by ticking from a list of options provided, the areas of agricultural extension services or types of information disseminated using the mobile phone. The list included: farming practices, availability of new crop varieties, credit sources, pest control, labour availability, health information etc.

\section{Results and Discussion}

\section{Provision of Mobile Phone and its Accessories by ADP}

Table 1 shows provision of support for information dissemination by Delta state ADP. Majority $(98.4 \%)$ of the respondents noted that they were not provided with mobile phone or airtime for information dissemination to farmers. This finding is in line with the findings of Ovighwo, Ifie, Ajobo and Akor (2009) that there are no provisions for mobile phones in Delta sate ADP. 
It is evident that ADP still relies heavily on individual contact method which is very cumbersome and time consuming; and does not possess the advantage of meeting/reaching large number of farmers within a limited period.

One way Delta state ADP could increase the number of farmers they disseminate information to will be to collaborate with network providers. Collaborations could be in the form of sending short messages or making of programmed short calls to farmers who are in their database. Also, providing a hotline service within the organization will speed up the ease of reaching farmers as answers are provided on immediate issues requiring urgent attentions.

On ownership of mobile phones, about $97 \%$ of the respondents affirmed that they possess their personal mobile phones. Also, about $92 \%$ of them noted that they use their personal mobile phones to disseminate information to farmers. The respondents also affirmed that they use calls $(84.4 \%)$, SMS $(71.9 \%)$, both calls and SMS $(70.3 \%)$ to reach out to farmers. Interactions with some of the respondents revealed that the mobile phone is used in their extension work to quickly reach the farmers and also for their convenience. This was confirmed by about $91 \%$ of the respondents who noted that the use of mobile phones facilitated their extension work. On the use of calls and SMSs to reach farmers, Banmeke, Fapojuwo and Fakoya (2010) in their work noted that calls and SMSs are appropriate in the dissemination of information through the mobile phones. Also, despite the fact that mobile phones facilitates extension work and has been shown by Adesope, Asiabaka \& Agumagu (2007) to be the most needed ICT by extension staff, its institutional provision for extension agents in Delta state public extension service system is non-existent.

Also, lack of mobile phones provision possesses the capacity to limit effective monitoring of extension agents accountability. Extension agents accountability, according to Dillion (2012) can be achieved by having both farmers' and extension agents' data in the database for quick monitoring. Putting up impromptu calls during work hours can be used to check on an extension agent. This monitoring is also supported by Duflo, Rema \& Stephen (2007), which stated that mobile phones can be used to verify extension agents' visits.

On the other hand, as it regards collaborations with network providers, findings revealed that Delta state ADP had no collaboration with network providers but collaborated $(37.1 \%)$ with only state media houses, for example, Delta Broadcasting Services (DBS) and Nigeria Television Authority (NTA) Asaba. Also, there was absence of hotline (87.5\%) where clientele could phone in to get answers to their enquiries 
Table 1: Sources of mobile phone and its accessories for information dissemination by public extension system

\begin{tabular}{lc}
\hline Variables & $\%$ \\
\hline Provision of mobile phones and airtime by organization & 1.6 \\
Yes & 98.4 \\
No & 96.9 \\
Ownership of mobile phones & 3.1 \\
Yes & 92.2 \\
No & 7.8 \\
Usage of personal mobile phone for information dissemination & \\
Yes & 84.4 \\
No & 71.9 \\
Mode of information dissemination & 70.3 \\
Calls & \\
SMSs & 91.4 \\
Calls and SMSs & 8.6 \\
Facilitates communication & 0.0 \\
Yes & 37.1 \\
No & \\
Collaboration & 0.0 \\
With network providers & 87.5 \\
Availability of hotline in the organization & \\
Yes & \\
No &
\end{tabular}

Source: Field work, July 2012

Frequency of use of mobile phone in disseminating some agricultural information

Table 2 shows the mean scores for the frequency at which mobile phones is used to disseminate information to farmers. It was found that availability of new crop varieties $(\mathrm{M}=$ 2.1), and market for sale of crop produce $(M=2.0)$ were information frequently disseminated to farmers through the mobile phone. The standard deviations of the mean scores were all less than 1.0. This shows that all the respondents' individual scores in respect of frequency of use of mobile phones in disseminating information on some agricultural information did not vary much from the mean. 
Table 2: Mean distribution of frequency of use of mobile phone in the dissemination of the under listed information type

\begin{tabular}{lcc}
\hline Information type & Mean (M) & S. D \\
\hline Farming practices & 1.9 & 0.8 \\
Availability of new crop varieties & $2.1^{*}$ & 0.6 \\
Weather updates & 1.3 & 0.6 \\
Markets for purchase of crop inputs & 1.9 & 0.6 \\
Markets for sale of crop produce & $2.0^{*}$ & 0.6 \\
Market for acquiring livestock (e.g. purchase of birds & 1.7 & 0.7 \\
e.t.c.) & 1.7 & 0.8 \\
Market for sale of livestock produce & 1.4 & 0.6 \\
Veterinary services & 1.3 & 0.6 \\
Credit sources & 1.6 & 0.7 \\
Training & 1.1 & 0.3 \\
Availability of small business & 1.5 & 0.7 \\
Livestock production & 1.8 & 0.5 \\
Processing of farm produce & 1.4 & 0.6 \\
Storage practices & 1.9 & 0.7 \\
Pest control & 1.5 & 0.6 \\
Labour availability & &
\end{tabular}

Source: Field work, July 2012

\section{Areas of agricultural extension services/information disseminated using mobile phones}

Table 3 shows the areas of agricultural information that are disseminated using the mobile phones. About $84 \%$ of the respondents noted that they disseminate information on availability of new crop varieties using the mobile phones. While $73.4 \%, 70.3 \%, 62.5 \%$, $54.7 \%, 50.0 \%, 46.9 \%$ of the respondents, respectively, noted that they use mobile phones to disseminate information on issues such as: markets for purchase of crop inputs, market for sale of crop produce, farming practices (like fertilizer application), training, market for sale of livestock produce and market for purchasing livestock. This is in line with the findings of Banmeke, et al. (2010) that information such as markets for sale and purchase of farm produce, farming practices (like fertilizer application) and improved seeds and seedlings can be disseminated through the mobile phone.

It is evident from the above findings, that not all information needs of the farmers can be met through mobile phones. Those information needs that are less practical oriented are those usually disseminated through the mobile phones. These are usually information that clientele can process without the extension agents physical presence. 
Table 3: Percentage distribution of areas of agricultural extension services/type of information disseminated using the mobile telephone

\begin{tabular}{lc}
\hline Information type & $\%$ \\
\hline Farming practices & 62.5 \\
Availability of new crop varieties & 84.4 \\
Weather updates & 29.7 \\
Markets for purchase of crop inputs & 73.4 \\
Markets for sale of crop produce & 70.3 \\
Market for acquiring livestock (e.g. purchase of birds' & 46.9 \\
e.t.c.) & \\
Market for sale of livestock produce & 50.0 \\
Veterinary services & 37.5 \\
Credit sources & 26.6 \\
Training & 54.7 \\
Availability of small business & 17.2 \\
Livestock production & 26.6 \\
Processing of farm produce & 46.9 \\
Storage practices & 40.6 \\
Crop production & 59.4 \\
Pest control & 67.2 \\
Labour availability & 45.3 \\
\hline
\end{tabular}

Source: Field work, July 2012

\section{Conclusion and recommendation}

From the findings, it can be concluded that the public extension service in Delta state has no institutional mobile phones for information dissemination as the EAs used personally owned mobile phone for disseminating information to farmers. There is need for the institution (Delta state public extension service) to make these devices (mobile phones) available in order to enhance information dissemination on a more frequent basis and reduce the dependency on individual contact method of extension service delivery. In addition, the presidential initiative on growth enhancement support scheme where farmers are to get agro-inputs through mobile phones, need to ensure that frontline extension agents are also provided with this device to ensure effective information delivery. On the other hand, Delta state ADP should collaborate with network providers in dissemination of short programmed messages or calls that are beneficial to their clientele; as such collaborations will facilitate information dissemination to farmers. Finally, it is important for Delta state ADP to create a hotline desk. This will readily provide answers to immediate needs of the farmers as answers to urgent needs of the farmers will be met more quickly.

\section{References}

Adesope, O. M., Asiabaka, C. C., and Agumagu, A.C. (2007). Effect of personal characteristics of extension managers and supervisors on information technology needs in Niger delta area of Nigeria. International Journal of Education and Development Using ICT, 3(2).

Agumagu, A. C., Adesope, O. M., Matthews-Njoku, E. C. and Nwaogwugwu, O. N (2008). Availability, access and frequency of information usage and communication technology among extension managers in the Niger Delta area of Nigeria. NJRS Vol. 8 (2). 
Aker, J. C. and Mbiti I. (2010). Mobile phones and economic development in Africa. Journal of Economic Perspectives, vol. 24(3), pp. 207-232.

Aker, J. C., (2011). Dial "A" for agriculture: A review of information and communication technologies for agricultural extension in developing countries. Available at http://www.cgdev.org/files/1425497 file Aker A for Agriculture FINAL.pdf. Retrieved on $21 / 10 / 2011$

Akpomuvie, O. B. (2010). Towards effective use of ICTS and traditional media for sustainable rural transformation in Africa. Journal of Sustainable Development, vol. 3(4), pp 165 - 170. Retrieved on 9/5/11

Banmeke, T. O. A., Fapojuwo, O. E and Fakoya, E. O. (2010). Extension agents' perception of the use of mobile phones to disseminate information to farmers in Edo state, Nigeria. Available online: http://kolaadebayo.multiply.com/journal/item/24/JSD-vol.-7. Retrieved 21/8/12

Dillion, B. (2012). Using mobile phones to collect panel data in developing countries. Journal of International Development, vol. 24(4), pp 518 - 527. Retrieved on 21/8/12

Duflo, E., Rema H and Stephen R. (2007). Monitoring Works: Getting Teachers to Come to School. BREAD Working Paper No. 103, pp 1 - 58. Retrieved on 21/8/12

International Telecommunication Union (ITU) (2007). Connect Africa summit-background paper - session Three. Extending Rural ICT Access in Africa. Available at http://www.itu.int/ITU-D/connect/africa/2007/summit/pdf/s3-backgrounder.pdf. _ (17 March, 2011)

ITU (2009). Information Society Statistical Profiles 2009:Africa. Geneva: International Telecommunications Union.

Ovighwo, B. O, Ifie, P. A., Ajobo, R. T. and Akor, E. I. (2009). The availability and use information communication and technologies by extension agent's in Delta Agricultural Development Project, Delta state, Nigeria. J. Hum Ecol., vol. 27(3), pp. 185 - 188. Available online: http://www.krepublishers.com/02-Journals/JHE/JHE-27-0-000-09Web/JHE-27-3-000-09-Abst-PDF/JHE-27-03-185-09-1924-Ovwigho-B-O/JHE-27-03185-09-1924-Ovwigho-B-O-Tt.pdf. Retrieve on 27/3/12

Umeh, G.N. (2008). Assessment of mass media usage for farm information by farmers in Afikpo LGA of Ebonyi State: Implication for information and communication technology (ict) application to agricultural technology transfer. Continental J. Information Technology, vol. $2, \quad$ pp. $9 \quad-\quad 12 . \quad$ Available at: http://ia600606.us.archive.org/22/items/AssessmentOfMassMediaUsageForFarmInfor mationByFarmersInAfikpoLgaOf/ContJInfoTech-9-12.pdf. Retrieved on 9/5/11 